\title{
Poly (ADP-ribose) polymerase inhibitor increases apoptosis and reduces necrosis induced by a DNA minor groove binding methyl sulfonate ester
}

\author{
L Tentori ${ }^{1}$, A Balduzzi $i^{1,5}$, I Portarena ${ }^{1,5}$, L Levati, P Vernole ${ }^{3}$, \\ B Gold ${ }^{4}$, E Bonmassar ${ }^{1,2}$ and G Graziani ${ }^{*, 1}$ \\ 1 Pharmacology and Medical Oncology Section, Department of Neuroscience, \\ University of Rome 'Tor Vergata', Via di Tor Vergata 135, 00133 Rome, Italy \\ 2 'Istituto Dermopatico dell'Immacolata' (IDI, IRCCS), Via dei Monti di Creta 104, \\ 00167 Rome, Italy \\ ${ }^{3}$ Department of Public Health and Cell Biology, University of Rome Tor Vergata, \\ Rome, Italy \\ ${ }^{4}$ Eppley Institute for Research in Cancer and Allied Diseases and Department of \\ Pharmaceutical Sciences, University of Nebraska Medical Center, Omaha, \\ Nebraska, NE 68198-6805, USA \\ 5 These authors equally contributed to the work \\ * Corresponding author: G Graziani, Department of Neuroscience, University of \\ Rome Tor Vergata, Via di Tor Vergata 135, 00133 Rome, Italy. \\ Tel: +39-0672596335/8; Fax: +39-0672596323 E-mail: graziani@uniroma2.it
}

Received 31.10.00; revised 2.2.01; accepted 12.2.01

Edited by TG Cotter

\begin{abstract}
The poly(ADP-ribose) polymerase (PARP) is involved in cell recovery from DNA damage, such as methylation of N3-adenine, that activates the base excision repair process. In the present study we demonstrated that $\mathrm{MeOSO}_{2}\left(\mathrm{CH}_{2}\right)_{2}$-lexitropsin (Me-Lex), a methylating agent that almost exclusively produces N3-methyladenine, induced different modalities of cell death in human leukemic cell lines, depending on the presence of PARP inhibitor. Growth inhibition, provoked by the combination of Me-Lex and PARP inhibitor, was associated with a marked down-regulation of c-myc, increased generation of single strand breaks and apoptosis. When used as single agent, at concentrations that saturated cell repair ability, Me-Lex induced mainly cell death by necrosis. Surprisingly, addition of a PARP inhibitor enhanced apoptosis and reduced the early appearance of necrosis. Telomerase activity was completely suppressed in cells exposed to Me-Lex alone, by $24 \mathrm{~h}$ after treatment, whereas it did not change when Me-Lex was combined with PARP inhibitor. Thereafter, inhibition of telomerase was observed with both treatments. The results suggest new insights on different modalities of cell death induced by high levels of N3-methyladenine per se, or by the methylated base in the presence of PARP inhibitor. Cell Death and Differentiation (2001) 8, 817-828.
\end{abstract}

Keywords: apoptosis; necrosis; telomerase; poly(ADP-ribose) polymerase; methylating agents; drug resistance
Abbreviations: PARP, poly(ADP-ribose) polymerase; Me-Lex, $\mathrm{MeOSO}_{2}\left(\mathrm{CH}_{2}\right)_{2}-\mathrm{N}$-methylpyrrole carboxamide dipeptide [MeO$\mathrm{SO}_{2}\left(\mathrm{CH}_{2}\right)_{2}$-Lexitropsin]; BER, base excision repair; N3-MeA, N3methyladenine; MPG, 3-methyladenine-DNA glycosylase; $O^{6}$. MeG, $\mathrm{O}^{6}$-methylguanine; MRS, mismatch repair system; $A B$, 3aminobenzamide; PI, propidium iodide; AMC, 7-amino-4-methylcoumarin; AV, annexin V; TRAP, telomeric repeat amplification protocol; GAPDH, glyceraldehyde-3-phosphate dehydrogenase; hTERT, human telomerase catalytic subunit; $h$ TR, RNA component of humantelomerase; RT - PCR, reverse-transcription polymerasechain reaction.

\section{Introduction}

The poly(ADP-ribose) polymerase (PARP) is a nuclear protein that detects DNA strand breaks generated by genotoxic agents such as monofunctional alkylating compounds, oxygen radicals and ionizing radiations. ${ }^{1}$ At the site of DNA damage, PARP binds to strand breaks and induces poly(ADP-ribosylation) of nuclear proteins using $\mathrm{NAD}+$ as substrate. As a consequence of PARP intervention, strand interruptions are converted into intracellular signals that activate DNA repair or necrosis, depending on the entity of damage. Cell death consequent to PARP activation is likely due to depletion of ATP pool, that follows NAD+ consumption. ${ }^{2}$ Moreover, PARP is cleaved and inactivated by caspases, during early stages of apoptosis. ${ }^{3,4}$ This would ensure appropriate execution of programmed cell death, preventing necrosis or avoiding DNA repair. ${ }^{5}$

With regard to DNA repair process, PARP plays a central role in base excision repair (BER) activity by recruiting the repair apparatus to the site of damage. ${ }^{2}$ The function of BER is to detect and remove the modified bases induced by a number of DNA-damaging agents, including antitumor drugs that generate N3-methyladenine adducts (N3-MeA). In this case, a specific 3-methyladenineDNA glycosylase (MPG) catalyzes the excision of the Nmethylpurine and the resulting apurinic site is processed by the sequential intervention of endonuclease, X-ray repair cross-complementing 1 (XRCC1), polymerase $\beta$ and ligase III. ${ }^{6,7}$

Unrepaired N3-MeA is a highly toxic lesion ${ }^{8}$ and tumor cell susceptibility to the lethal effects induced by N3-MeA inversely correlates with the levels of MPG activity. ${ }^{9}$ This is specially the case of methylating agents that generate almost exclusively N3-MeA $(>99 \%)$, such as $\mathrm{MeOSO}_{2}\left(\mathrm{CH}_{2}\right)_{2}$-lexitropsin (Me-Lex), a methyl sulfonate ester tethered to $\mathrm{N}$-methylpyrrolecarboxamide dipeptide that targets $A / T$ rich sequences located in the DNA minor groove. ${ }^{10,11}$ Conversely, in the case of the imidazotetrazine temozolomide, which 
alkylates DNA at different base sites (70\% N7-G, 9\% N3-A, $5 \% \mathrm{O}^{6}-\mathrm{G}$ ), the low levels of N3-MeA adducts generated by the drug are rapidly repaired by BER system and do not substantially contribute to the overall toxicity of the agent. $^{12}$ The N7-methylguanine adduct appears to have little or no lethal effects, whereas $O^{6}$. methylguanine $\left(\mathrm{O}^{6}-\mathrm{MeG}\right)$ is generally considered the main cytotoxic and mutagenic lesion produced by temozolomide. $^{13}$ In fact, if not repaired by $\mathrm{O}^{6}$. alkylguanine-DNA alkyltransferase, $\mathrm{O}^{6}-\mathrm{MeG}$ pairs inappropriately either with thymine or cytosine and triggers the intervention of the mismatch repair system (MRS). However, MRS fails to find a correct partner for the methylated base, generates nicks in the DNA, and activates the apoptotic machinery. ${ }^{14}$

Defects in the MRS pathway, that are frequently detected either in hematological malignancies or in solid tumors, render tumor cells resistant to the cytotoxic effects of $\mathrm{O}^{6}$-MeG adducts generated by $\mathrm{O}^{6}$-G-methylating agents. ${ }^{15}$ Moreover, MRS-deficient tumors also show poor responsiveness to other antineoplastic agents, such as 6thioguanine, cisplatin and topoisomerase inhibitors. ${ }^{16}$ On the other hand, MRS-deficient tumor cells are susceptible to cytotoxicity mediated by the N3-MeA inducing agent. In particular, we previously demonstrated that the use of PARP inhibitor renders cytotoxic low Me-Lex concentrations which induce a level of DNA damage that do not saturate cell repair ability. This effect is accompanied by p53 induction, enhanced clastogenicity and up-regulation of XRCC1 transcript. ${ }^{9}$

In the presence of PARP inhibitor, it can be hypothesized that DNA damage might be consequential to strand breaks generated by interruption of BER processes after the removal of the damaged nucleotide. Conversely, the N3-MeA adduct per se appears to behave as a replication blocking lesion, since it blocks the contact between DNA polymerase and the adenine in the DNA template strand. ${ }^{8}$ Therefore, different types of DNA damage might trigger distinct cell death pathways.

The aim of the present study is to evaluate the kinetics and mode of cell death, and strand breaks induced by the selective N3-A methylating agent MeLex, at concentrations that saturate the repair ability of tumor cells. Data were compared with those obtained by combining Me-Lex with the PARP inhibitor 3aminobenzamide $(A B)$. Noteworthy, in view of their essential role in cell proliferation and immortalization, expression of c-myc and telomerase activity were also investigated.

The results presented here show that growth inhibition provoked by the combination of Me-Lex and PARP inhibitor was associated with a marked c-myc downregulation. When used as single agent, at concentrations that saturate repair ability of the cells, Me-Lex induced mainly cell death by necrosis and suppression of telomerase activity. The addition of PARP inhibitor enhanced apoptosis, reduced the early appearance of necrosis and delayed down-regulation of telomerase activity.

\section{Results}

\section{PARP inhibitor enhances growth inhibition and c-myc down-regulation induced by Me-Lex}

Leukemia Jurkat and MT-1 cells, are characterized by high and low basal levels of MPG activity, respectively, and different sensitivity to cytotoxic effects induced by N3methyladenine. ${ }^{9}$ Both lines were exposed to graded concentrations of Me-Lex, alone or combined with PARP inhibitor. The influence of drug treatment on cell growth and c-myc expression was evaluated $24 \mathrm{~h}$ after treatment. The results, illustrated in Figure 1, indicated that $A B$ enhanced the growth inhibitory effect induced by the N3-A methylating agent. In MT-1 cells this effect was especially evident at low Me-Lex concentrations (1.5-6.2 $\mu \mathrm{M})$. Moreover, high concentrations of Me-Lex (25 $\mu \mathrm{M}$ in MT-1 and $50 \mu \mathrm{M}$ in Jurkat cells) were capable of suppressing cell growth similarly to the drug combination of Me-Lex and AB (Figure 1).

Northern blot analysis of c-myc transcript indicated a concentration-dependent reduction of c-myc expression in MT-1 and Jurkat cells treated with the drug combination. This effect paralleled growth inhibition induced by $\mathrm{Me}$ Lex $+A B$. In the case of treatment with the methylating agent alone, a marked decrease of c-myc transcript was detected only at the highest Me-Lex concentrations tested (12.5 and $25 \mu \mathrm{M}$ for $\mathrm{MT}-1$ cells or $50 \mu \mathrm{M}$ for Jurkat cells).

\section{PARP inhibitor increases apoptosis and reduces necrosis induced by Me-Lex}

We have investigated whether treatment with Me-Lex, as single agent or combined with $\mathrm{AB}$, might be accompanied by a distinct pattern or kinetics of cell death. Flow cytometry analysis of hypodiploid DNA content, that allows detection of cells at a late stage of the apoptotic process, was performed in MT-1 and Jurkat cells. The results, obtained at $24 \mathrm{~h}$ after treatment, show that after ethanol fixation and staining with propidium iodide $(\mathrm{PI})$, the percentage of hypodiploid apoptotic cells was at least twofold higher in cells treated with Me-Lex $(6.2-25 \mu \mathrm{M})$ combined with $\mathrm{AB}$, than in cells exposed to equal concentrations of the methylating agent alone (Figure 2). Moreover, PI staining of non-fixed cells showed the prevalence of necrotic cells in the groups treated with Me-Lex (Figure 2).

Apoptosis induction by the combined treatment with MeLex and $\mathrm{AB}$ was confirmed by assessment of caspase-3 activation, which is considered an early marker of apoptosis. ${ }^{17}$ Caspase-3 activity was evaluated by cleavage of a fluorogenic substrate in untreated or drug treated MT-1 cells. The results indicate that cell lysates corresponding to samples treated with Me-Lex (25$12.5 \mu \mathrm{M})+\mathrm{AB}$ released fluorescent substrate, indicating the presence of caspase- 3 activity (Figure $3 \mathrm{~A}$ ). Addition of the specific inhibitor Ac-DEVD-CHO abrogated caspase3 mediated cleavage of the fluorogenic peptide. Caspase-3 activity was absent in samples treated with only Me-Lex or in untreated and $A B$ treated controls (Figure $3 A$ ). Caspase- 3 activation was also detected in Jurkat cells treated with $50 \mu \mathrm{M}$ Me-Lex+AB, whereas enzymatic 

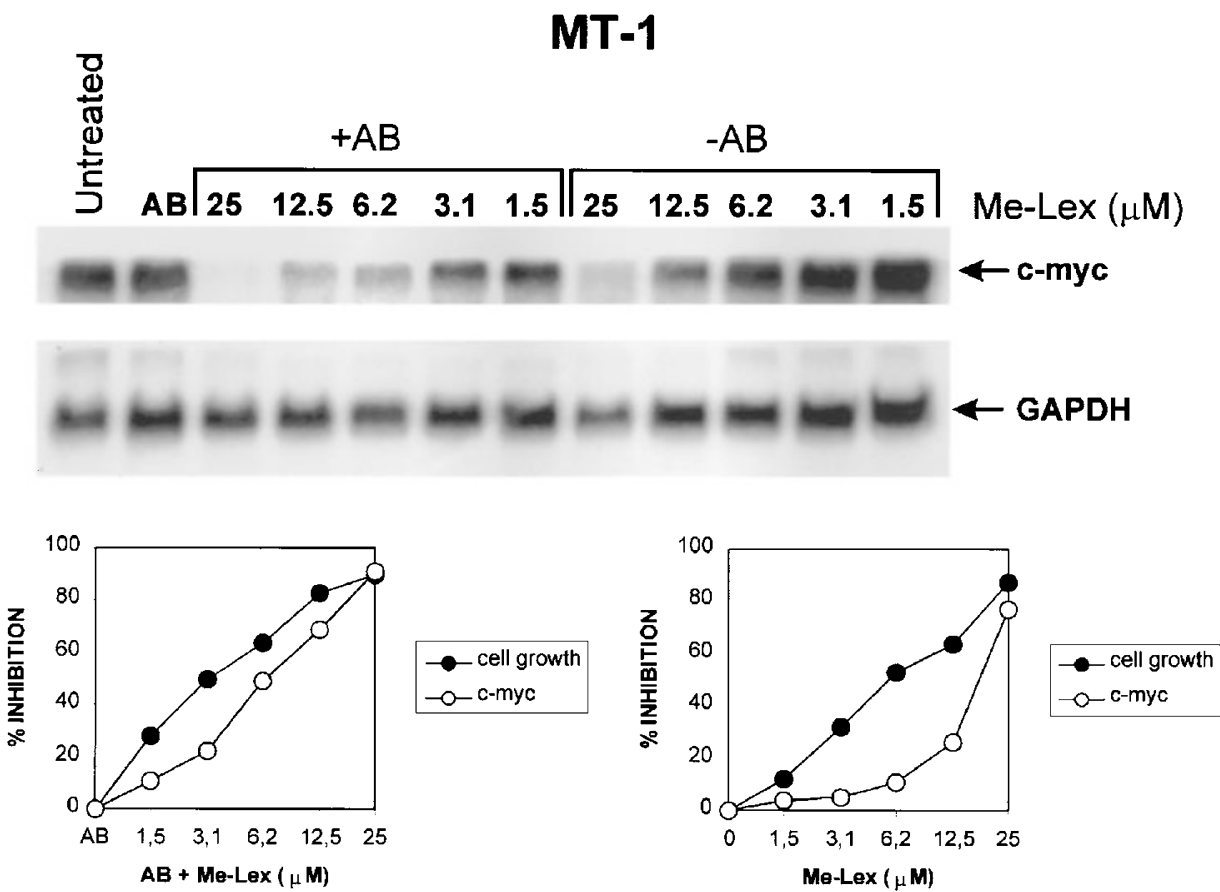

\section{JURKAT}
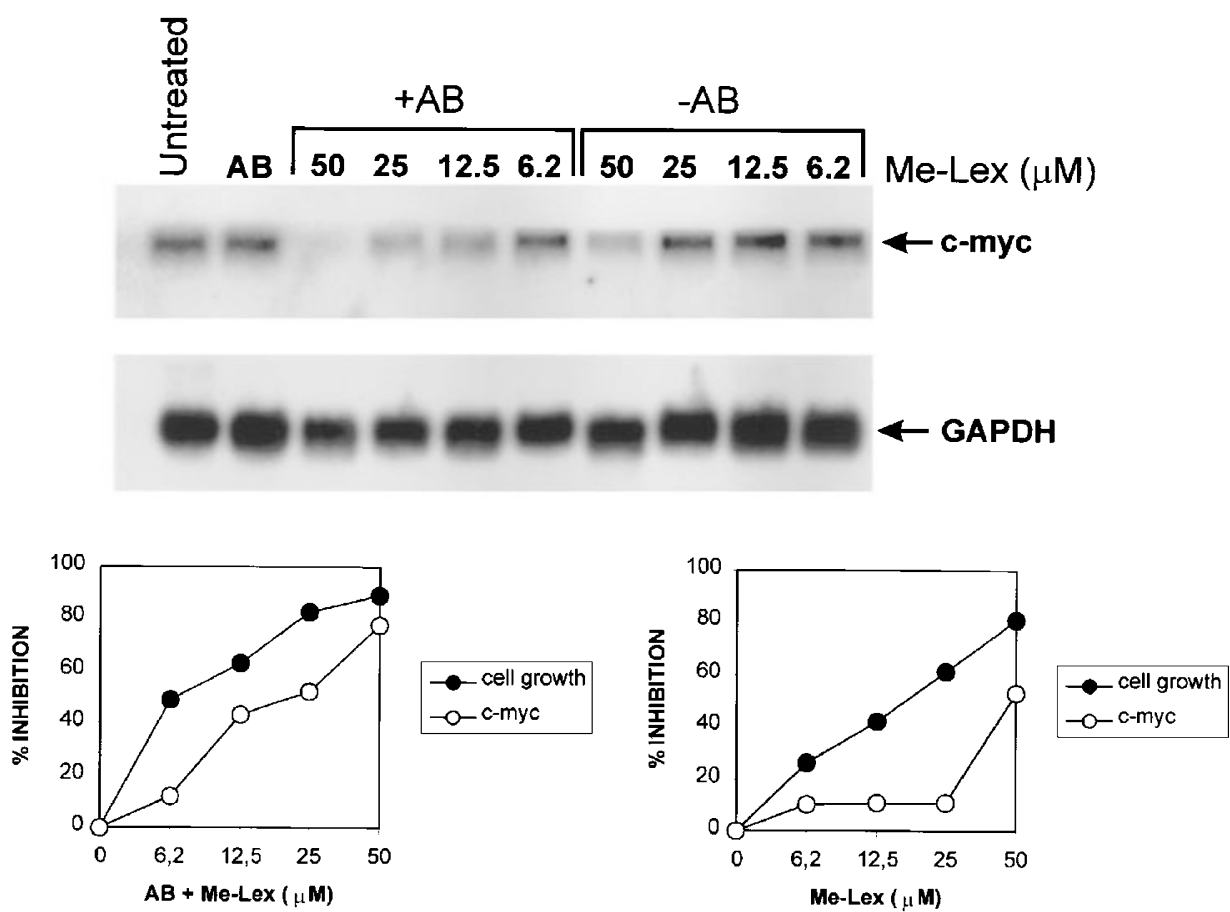

Figure 1 Growth inhibition and c-myc expression in MT-1 and Jurkat cells after treatment with Me-Lex, as single agent or combined with PARP inhibitor. Tumor cells were exposed to the drugs, and growth and c-myc transcript were assessed $24 \mathrm{~h}$ later. Expression of c-myc was tested by Northern blot analysis using $15 \mu \mathrm{M}$ of total RNA for each sample. Control of the integrity and amount of RNA loaded in each lane was performed by ethidium bromide staining of the gel (data not shown). Values indicating the percentages of growth inhibition $(\mathbf{0})$ were calculated comparing cell growth of cultures exposed to Me-Lex $\pm A B$, with that of untreated or $A B$ treated controls. Data represent the mean values of four independent experiments. Means were calculated following angular transformation of the percentage of inhibition values. Standard errors of the mean value never exceeded $10 \%$. The $\mathrm{IC}_{50} \mathrm{~S}$ of Me-Lex, calculated with the data of three independent experiments, were as follows: $6+0.3 \mu \mathrm{M}$ for MT-1 and $13+0.5 \mu \mathrm{M}$ for Jurkat cells. In the presence of $\mathrm{AB}$ the $\mathrm{IC}_{50} \mathrm{~S}$ were: $3+0.2 \mu \mathrm{M}$ for MT-1 and $6+0.2 \mu \mathrm{M}$ for Jurkat cells. Values indicating inhibition of c-myc transcript $(O)$ in drug treated cells with respect to untreated or $A B$ treated controls, refer to densitometric scanning of the autoradiograms presented in the Figure. The optical densities of the hybridization signals, corresponding to c-myc transcript, were normalized for glyceraldehyde-3-phosphate dehydrogenase (GAPDH) expression 
activity was not present in samples exposed to Me-Lex as a single agent (data not shown).

The kinetics of cell death induction was evaluated by annexin $\mathrm{V}(\mathrm{AV})$ and $\mathrm{PI}$ double-labeling that is commonly

A MT-1

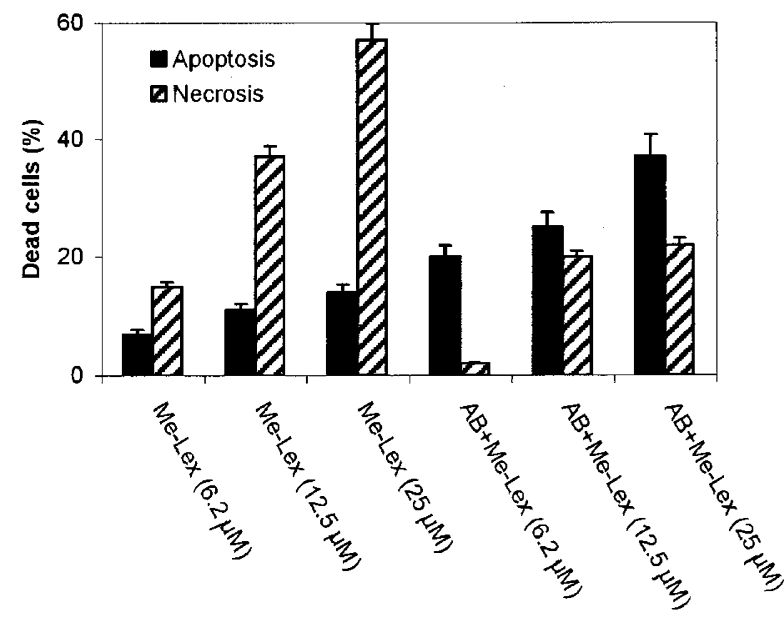

B

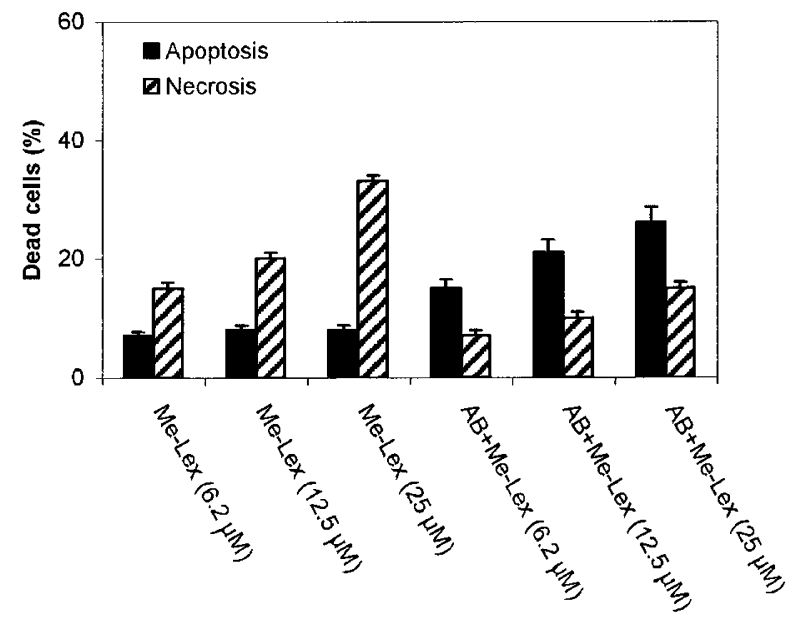

Figure 2 Apoptosis or necrosis induced by drug treatment in MT-1 and Jurkat cells. MT-1 or Jurkat cells were exposed to Me-Lex alone or combined with $A B$ for $24 \mathrm{~h}$. After treatment cells were fixed overnight in $\mathrm{EtOH}(70 \%)$ and apoptosis was measured by flow cytometry analysis of the subG1 DNA content. Simultaneously, an aliquot of unfixed cells was washed and resuspended in PBS and labeled with $2 \mu \mathrm{g} / \mathrm{ml}$ of PI. Necrotic cells, that have lost plasma membrane integrity, were positive for PI staining. Data are expressed as percentage of apoptotic or necrotic cells and represent the mean of three independent experiments $\pm S$.E. calculated following angula transformation of the percentage values. In untreated or $A B$ treated cells the percentage of apoptotic or necrotic cells never exceeded $3 \%$. Differences between the percentage of apoptotic cells induced by Me-Lex+AB and those induced by Me-Lex only were always statistically significant $(P<0.01$, according to Student's $t$-test). Analogously, differences between the percentage of necrotic cells induced by combined treatment and Me-Lex were always statistically significant $(P<0.01)$ used to discriminate early apoptotic cells from necrotic ones. In fact, apoptotic cell death is accompanied by a change in plasma membrane structure evidenced by surface exposure of phosphatidylserine, that can be detected by AV staining. ${ }^{18}$ In addition, apoptotic cells exclude DNA dyes, such as PI, being plasma membrane integrity preserved. In contrast, necrotic cells rapidly lose membrane function and integrity, thus allowing access to $\mathrm{PI}$ and binding of AV to the inner face of plasma membrane.

Untreated or drug treated MT-1 or Jurkat cells were collected at different time points after exposure to Me-Lex, and stained with $\mathrm{PI}$ and $\mathrm{AV}$. The results, illustrated in Figure 4, refer to flow cytometry analysis of MT-1 cells treated with $25 \mu \mathrm{M}$ Me-Lex, alone or combined with $\mathrm{AB}$. As early as $3 \mathrm{~h}$ after treatment, a marked reduction of viable cells $(\mathrm{PI}-\mathrm{AV}-$ ) and an increase in necrotic cells $(\mathrm{PI}+\mathrm{AV}-$ and $\mathrm{PI}+\mathrm{AV}+)$ was observed when the MT-1 line was treated with Me-Lex (Figure 4B). At $6 \mathrm{~h}$ a further increase of the percentage of necrotic cells was observed (Figure $4 \mathrm{C}$ ). At 3 and $6 \mathrm{~h}$, the percentage of apoptotic cells $(\mathrm{PI}-\mathrm{AV}+)$ was not substantially different from that detected in cells treated with the drug combination (Figure 4, $B, C$ vs $F, G$ ). In Me-Lex+AB group, the number of apoptotic cells markedly increased during the time of culture, whereas the total number of necrotic cells remained unchanged (Figure 4, F,G,H). Interestingly, at $24 \mathrm{~h}$ necrosis was predominant in the group treated with the single agent (Figure 4D), whereas apoptosis prevailed in cells exposed to the drug combination (Figure $4 \mathrm{H}$ ). In both cases, at $48 \mathrm{~h}$ the majority of cells were $\mathrm{PI} / \mathrm{AV}$ double-positive (data not shown).

In order to verify that cell death provoked by a necrotic stimulus is accompanied by the appearance of $\mathrm{AV}-\mathrm{PI}+$ together with double positive cells, the kinetics of induction of $\mathrm{AV}-\mathrm{PI}+$ and $\mathrm{AV}+\mathrm{PI}+$ subsets was assessed by exposing MT-1 cells to a necrotic stimulus. The results, illustrated in Table 1, indicate that heat shock at $60^{\circ} \mathrm{C}$ induced an elevated number of $\mathrm{PI}+\mathrm{AV}$ - cells, that preceded the progressive increase of necrotic $\mathrm{PI}+\mathrm{AV}+$ cells.

In the case of Jurkat cells the appearance of necrosis was observed at $6 \mathrm{~h}$ in cells treated with $50 \mu \mathrm{N}$ Me-Lex alone (Figure 5B), whereas a remarkable percentage of apoptotic cells was detected in cells exposed to the drug combination (Figure 5E). At $24 \mathrm{~h}$ apoptosis was still prevalent in the group treated with Me-Lex+AB (Figure 5F), whereas necrosis predominated in cells treated with the single agent (Figure 5C). A comparable reduction of viable cells was observed in both groups (Figure 5).

\section{Me-Lex treatment modulates telomerase activity}

We previously demonstrated that suppression of telomerase activity can be considered an indicator of drug-induced cytotoxicity against cancer cells, when a reduction of telomerase activity, with respect to untreated control, is observed in cell extracts corresponding to equal volume of treated cultures. ${ }^{19-21}$ In the present study, instead, we have investigated whether the distinct timing of induction and 
A

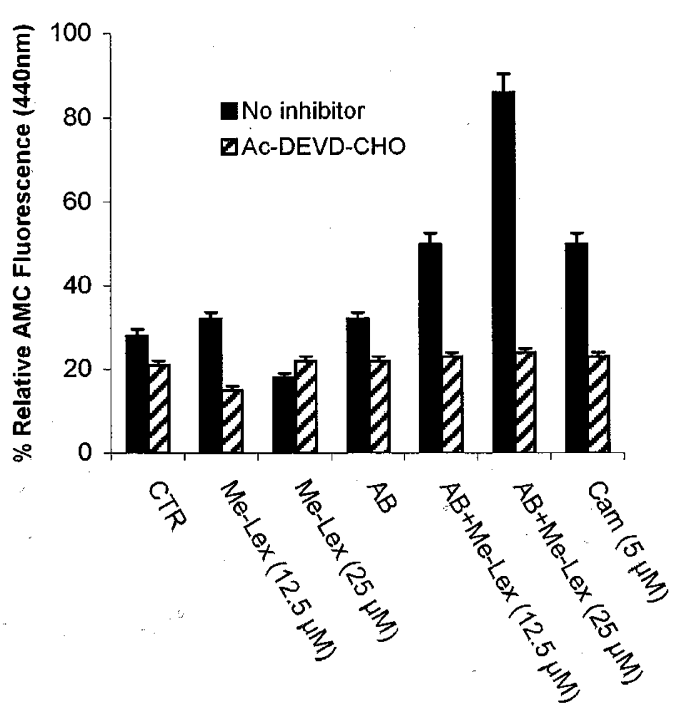

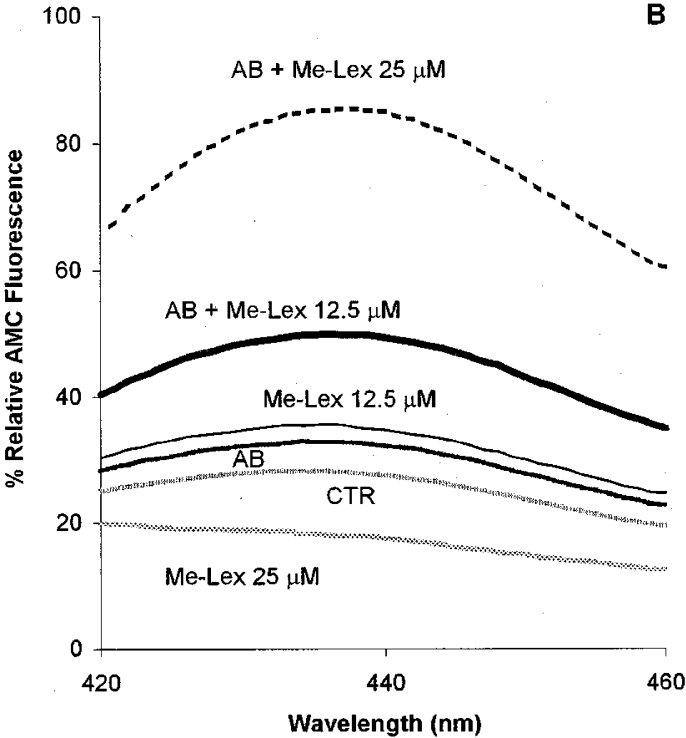

Figure 3 Caspase-3 activity in MT-1 cells treated with Me-Lex \pm AB. (A) Cells were collected $15 \mathrm{~h}$ after drug treatment and then processed for caspase-3 assay. As a control for apoptosis induction cells were treated with Camptothecin (Cam). The results are expressed as percentage of AMC fluorescence at $440 \mathrm{~nm}$ wavelength. Data represent the mean of three independent experiments \pm S.E. calculated following angular transformation of the percentage values. (B) Spectrofluorometric analysis of cell lysates from selected groups. Data are from a representative experiment

A
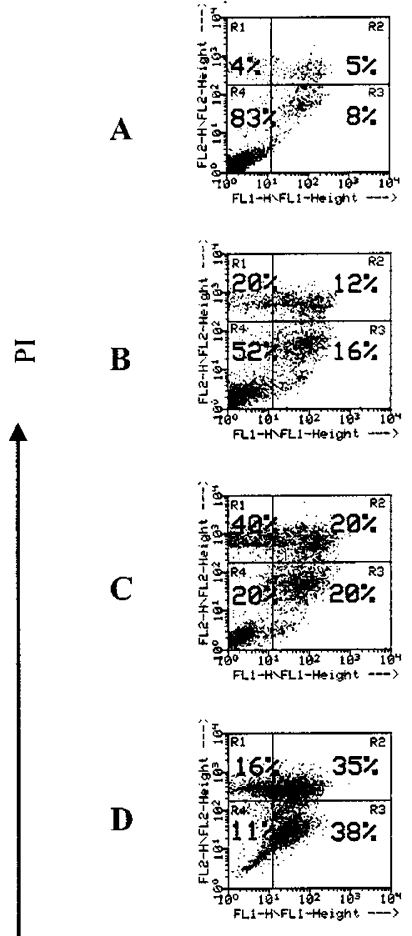

$\mathbf{E}$

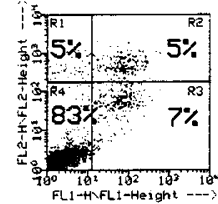

$\mathbf{F}$

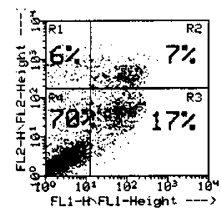

G

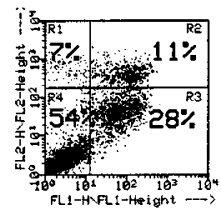

H

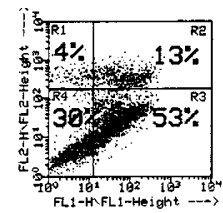

\section{ANNEXIN V}

Figure 4 Apoptosis and necrosis induced by drug treatment in MT-1 cells. Cells, treated with $25 \mu \mathrm{M}$ Me-Lex $\pm A B$, were collected at 3,6 and $24 \mathrm{~h}$ after drug exposure. After treatment, cells were stained with annexin V (AV) and PI. The percentages of necrotic ( $\mathrm{R} 1, \mathrm{Pl}+\mathrm{AV} ; \mathrm{R} 2, \mathrm{Pl}+\mathrm{AV}+)$, apoptotic $(\mathrm{R} 3, \mathrm{PI}-\mathrm{AV}+)$ or viable cells $(\mathrm{R} 4, \mathrm{PI}-\mathrm{AV}-)$ are indicated. Untreated control, $(\mathrm{A})$ cells treated $25 \mu \mathrm{M} \mathrm{Me}$-Lex for $3 \mathrm{~h},(B) 6 \mathrm{~h},(C)$ and $24 \mathrm{~h}$ (D). Control treated with $\mathrm{AB}$ for $24 \mathrm{~h}$, (E) or with $25 \mu \mathrm{M} \mathrm{Me}-\mathrm{Lex}+\mathrm{AB}$ for $3 \mathrm{~h},(\mathbf{F}), 6 \mathrm{~h},(\mathbf{G})$ and $24 \mathrm{~h}(\mathbf{H})$. Data are representative of one out of three experiments with comparable results

Table 1 Bivariate Annexin V/PI analysis of MT-1 cells subjected to a necrotic stimulus

\begin{tabular}{lcccc}
\hline & PI $-\mathbf{A V}-$ & $\mathbf{P I}-\mathbf{A V}+$ & $\mathbf{P I}+\mathbf{A V}-$ & $\mathbf{P I}+\mathbf{A V +}$ \\
\hline Control & $85 \%$ & $5 \%$ & $5 \%$ & $5 \%$ \\
$1 \mathrm{~h}$ & $5 \%$ & $0 \%$ & $66 \%$ & $29 \%$ \\
$3 \mathrm{~h}$ & $1 \%$ & $0 \%$ & $60 \%$ & $39 \%$ \\
$6 \mathrm{~h}$ & $0 \%$ & $0 \%$ & $38 \%$ & $62 \%$ \\
$18 \mathrm{~h}$ & $0 \%$ & $0 \%$ & $30 \%$ & $70 \%$ \\
\hline
\end{tabular}

MT-1 cells were heated at $60^{\circ} \mathrm{C}$ for $30 \mathrm{~min}$ and then cultured for $1-18 \mathrm{~h}$ as indicated. Cells were then stained with Annexin V and PI

modalities of cell death induced by Me-Lex or by Me-Lex+AB might be accompanied by different kinetics of reduction in telomerase activity. For this purpose cell extracts corresponding to equal number of cells were used for the telomeric repeat amplification protocol (TRAP) assay, 6, 24, 48 and $72 \mathrm{~h}$ after treatment with Me-Lex $(6.2-50 \mu \mathrm{M})$, alone or combined with AB. At $6 \mathrm{~h}$, a marked decrease of telomerase activity $(80 \%$ reduction with respect to untreated control) was observed only in MT-1 cells treated with $50 \mu \mathrm{M}$ Me-Lex (data not shown). At $24 \mathrm{~h}$, telomerase activity was abrogated $(25-50 \mu \mathrm{M})$ or profoundly reduced $(12.5 \mu \mathrm{M})$ in MT-1 cells treated with MeLex only (Figure 6). Unexpectedly, telomerase activity remained elevated when equal Me-Lex concentrations were combined with $A B$ (Figure 6), even though the cytotoxic effect was comparable $(25-50 \mu \mathrm{M})$ or higher $(12.5 \mu \mathrm{M})$ than that induced by Me-Lex alone. At $48 \mathrm{~h}$, telomerase activity decreased also in cells treated with Me-Lex combined with PARP inhibitor (data not shown). At $72 \mathrm{~h}$, telomerase activity was suppressed either in cells exposed to Me-Lex (12.5$50 \mu \mathrm{M})$ alone or in association with $\mathrm{AB}$. No substantial decrease in telomerase activity was detected in cells treated 
with $6.2 \mu \mathrm{M}$ Me-Lex $\pm \mathrm{AB}$ up to $72 \mathrm{~h}$ after drug treatment (Figure 6).

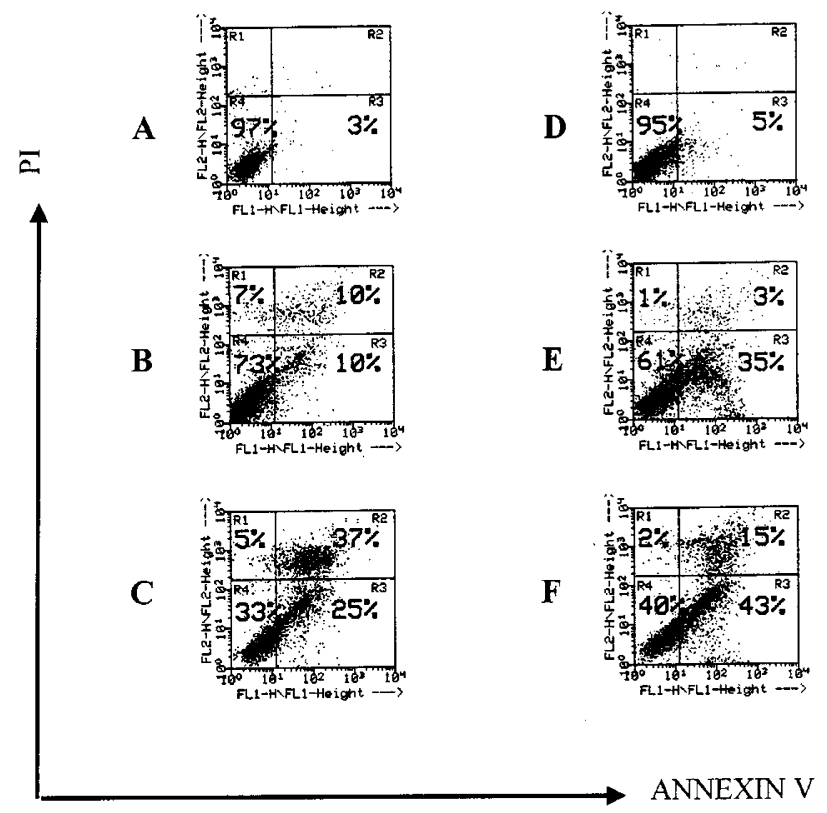

Figure 5 Apoptosis and necrosis induced by drug treatment in Jurkat cells Cells, treated with $50 \mu \mathrm{M} \mathrm{Me-Lex} \pm \mathrm{AB}$, were collected at 6 and $24 \mathrm{~h}$ after drug exposure. After treatment, cells were stained with Annexin V and PI. Untreated control, (A) cells treated $50 \mu \mathrm{M}$ Me-Lex for $6 \mathrm{~h},(B)$ and $24 \mathrm{~h}$, (C). Control treated with $A B$ for $24 \mathrm{~h},(\mathbf{D})$ or with $50 \mu \mathrm{M} \mathrm{Me}-\mathrm{Lex}+\mathrm{AB}$ for $6 \mathrm{~h}(\mathrm{E})$ and $24 \mathrm{~h}(\mathbf{F})$. After drug treatment, the different cell populations were identified by $A V$ and $P$ bivariate analysis as described in legend to Figure 2. The experiment was repeated once with comparable results
In Jurkat cells suppression of telomerase activity was observed only at the concentration of $50 \mu \mathrm{M}$, probably due to the lower susceptibility of these cells to Me-Lex, with respect to MT-1 (Figure 7). All samples showed comparable levels of alkaline phosphatase activity (data not shown). This enzyme possesses a stability similar to that of telomerase, thus serving as an internal control for the quality of the extracts.

Telomerase activity was assessed also in MT-1 cells subjected to a necrotic stimulus at different time points $(3,6$ and $18 \mathrm{~h}$ ). The results of TRAP assay indicated that heat shock profoundly suppressed telomerase $(90 \%$ reduction with respect to untreated control) as early as $3 \mathrm{~h}$ after heating (data not shown). At this time point, the entire cell population stained with PI (Table 1).

When MT-1 cell extracts were exposed to Me-Lex in vitro, this drug did not substantially affect telomerase activity (Figure $8 \mathrm{~A}$ ). Therefore, a direct influence of the methylating agent on telomerase enzyme is not involved in the reduction of the activity observed after treatment of tumor cells with Me-Lex. In addition, the drug was also devoid of inhibitory effect on Taq DNA polymerase, as assessed by adding Me-Lex directly to the PCR reaction mixture (data not shown).

Abrogation of telomerase activity observed with MeLex at $24 \mathrm{~h}(25-50 \mu \mathrm{M})$ was not due to the release from necrotic cells of factors capable of inhibiting TRAP assay. In fact, when aliquots of cell extracts prepared from untreated control were mixed with an equal volume of extracts, obtained from Me-Lex treated cells (25$50 \mu \mathrm{M})$, no changes in telomerase activity were detected (Figure 8B).

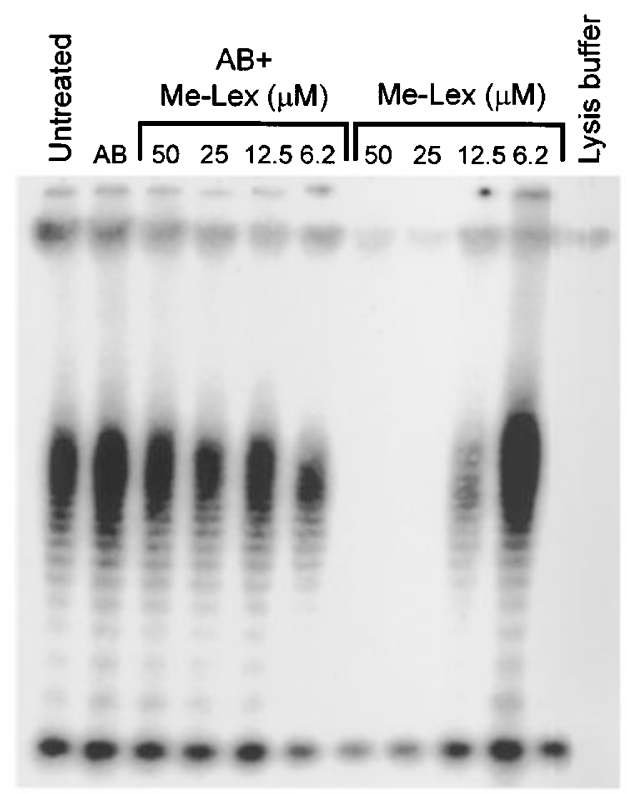

$24 \mathrm{~h}$

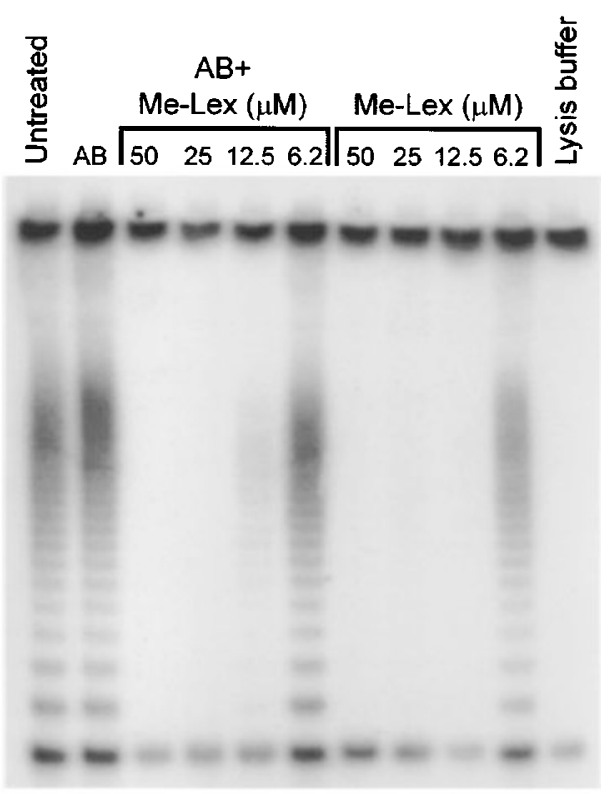

$72 \mathrm{~h}$

Figure 6 Reduction of telomerase activity in MT-1 cells treated with Me-Lex, alone or combined with AB. Telomerase activity was tested by TRAP assay using $2 \times 10^{2}$ cells, at 24 and $72 \mathrm{~h}$ post-treatment. As negative control, cell extract was replaced by an equal volume of lysis buffer 


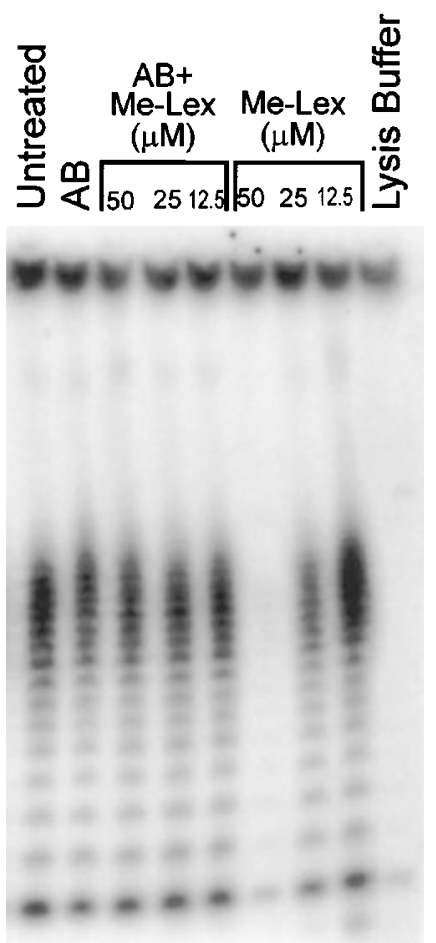

Figure 7 Influence of Me-Lex on Telomerase activity of Jurkat cells. Telomerase activity was tested by TRAP assay using $2 \times 10^{2}$ cells, at $24 \mathrm{~h}$ post-treatment. As negative control, cell extract was replaced by an equal volume of lysis buffer

Expression of human telomerase catalytic subunit (hTERT) and of the RNA component (hTR) of the enzyme were investigated by RT-PCR and Northern blot analysis, respectively. Cells were harvested $24 \mathrm{~h}$ after treatment and RNA was extracted from the entire cell population. The results, illustrated in Figure 9, indicated that hTERT transcripts markedly decreased in MT-1 cells treated with $25 \mu \mathrm{M}$ Me-Lex, alone or combined with PARP inhibitor. In contrast, hTR expression did not change in all samples.

\section{PARP inhibitor increases single strand break formation in MT-1 and Jurkat cells}

The single cell gel electrophoresis or comet assay using alkaline conditions can be used to measure single strand breaks, even those that are transiently formed during BER pathway. ${ }^{22}$ In our experimental conditions, inhibition of PARP activity would interrupt completion of the repair process of N3-MeA adducts induced by Me-Lex, thus generating unrepaired single strand breaks that might ultimately trigger cell death. To assess this hypothesis, MT-1 or Jurkat cells were exposed to 25-50 $\mu \mathrm{M}$ Me-Lex and single strand breaks were analyzed $3 \mathrm{~h}$ after treatment. The results (Table 2) indicated that in both cell lines PARP inhibitor significantly increased single strand breaks generated by Me-Lex.

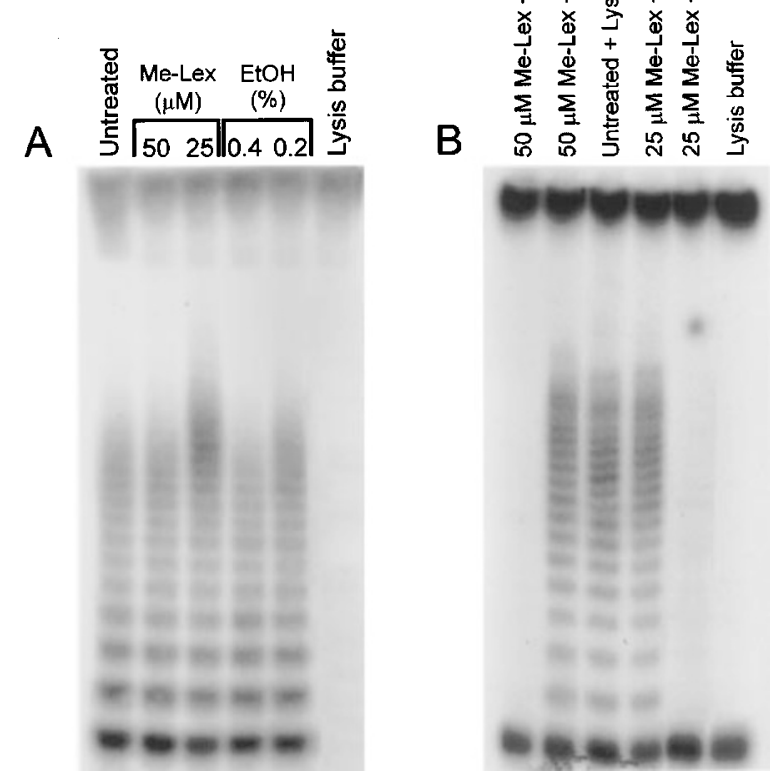

Figure 8 Addition of Me-Lex or of cell lysates from drug treated cells to extracts of untreated control did not affect telomerase activity. (A) In vitro direct effects of Me-Lex on telomerase activity. MT-1 cell extracts, corresponding to $2 \times 10^{2}$ cells, were exposed in vitro to the indicated concentrations of Me-Lex or of the drug vehicle (ethanol; EtOH) for $1 \mathrm{~h}$. (B) Influence of cell extracts obtained from Me-Lex treated cells on telomerase activity of untreated controls. Aliquots $(2 \mu \mathrm{l})$ of Me-Lex $(25-50 \mu \mathrm{M})$ treated MT1 extracts, corresponding to $10^{2}$ cells, were mixed with lysis buffer $(2 \mu \mathrm{l})$ or with equal aliquots of untreated cells and used for TRAP assay. As negative control, cell extract was replaced by an equal volume of lysis buffer

\section{Discussion}

Methylating agents that selectively target the N3 position of adenine, alone or combined with PARP inhibitors, appear to have a potential role to overcome drug resistance in MRSdeficient tumor cells. In the present study we demonstrated, for the first time, that the N3-methylating agent Me-Lex induced different modes of cell death, depending on the presence of PARP inhibitor. In fact, cytotoxic concentrations of Me-Lex induced early necrosis and down-regulation of telomerase activity, whereas, the same drug concentrations combined with $A B$, mostly provoked apoptosis and delayed reduction of telomerase activity.

The ability of an anticancer agent to induce apoptosis or necrosis depends on its mechanism of action, concentration and duration of exposure as well as biological properties of tumor cells. In our model the selective N3methylating agent was more cytotoxic in MT-1 cells, which express lower levels of MPG activity with respect to Jurkat cells. Noteworthy, in both cell lines, using elevated concentrations of Me-Lex, necrosis started at early time points and prevailed over apoptosis. In contrast, when associated with PARP inhibitor, Me-Lex induced a timedependent increase of the number of apoptotic cells. In this 
A

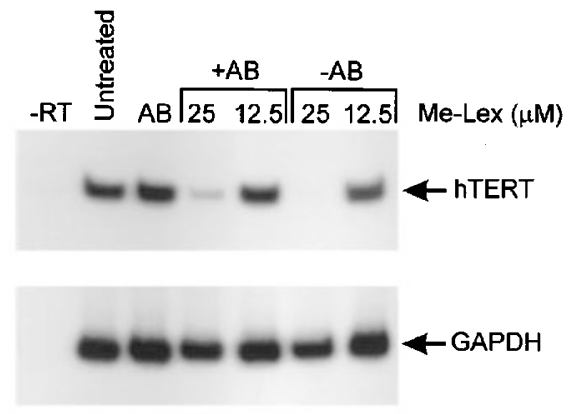

B

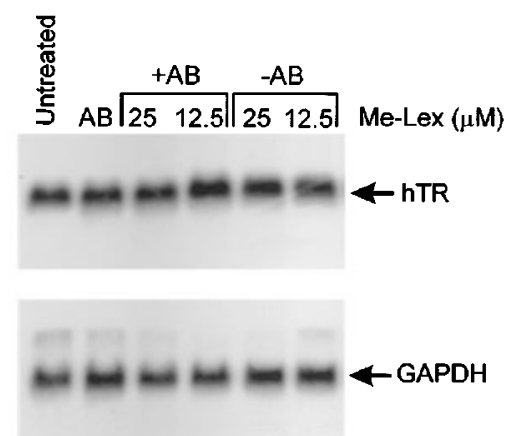

Figure 9 Expression of hTERT and hTR in drug treated tumor cells. (A) Messenger RNA was extracted from untreated or treated MT-1 cells $24 \mathrm{~h}$ after drug exposure. RNA samples were subjected to RT-PCR analysis, using hTERT or GAPDH specific primers. The experiment was repeated once with comparable results. -RT: RNA sample incubated in the absence of RT and then subjected to PCR amplification. (B) Northern blot analysis was performed using total RNA $(15 \mu \mathrm{g})$ extracted from MT-1 cells. The blot was hybridized sequentially with $\mathrm{hTR}$ and GAPDH probes. Control of the integrity and amount of RNA loaded in each lane was performed by ethidium bromide staining of the gel (data not shown). The results are representative of one out of three repeated experiments with comparable results

Table 2 Single strand breaks in cells exposed to Me-Lex, alone or combined to $A B$

\begin{tabular}{lcccc}
\hline Exp & Me-Lex & MT-1 & & \\
\hline$\# 1$ & $25 \mu \mathrm{M}$ & $16 \%$ & $\mathbf{+ A B}$ & $\mathbf{P}^{\mathbf{a}}$ \\
$\# 2$ & $25 \mu \mathrm{M}$ & $18 \%$ & $52 \%$ & $<0.001$ \\
$\# 1$ & $50 \mu \mathrm{M}$ & $12 \%$ & $42 \%$ & $<0.001$ \\
$\# 2$ & $50 \mu \mathrm{M}$ & $10 \%$ & $36 \%$ & $<0.01$ \\
& & & & \\
\hline \#1 & & Jurkat & & \\
$\# 2$ & $25 \mu \mathrm{M}$ & $33 \%$ & $86 \%$ & $<0.01$ \\
$\# 1$ & $25 \mu \mathrm{M}$ & $19 \%$ & $38 \%$ & $<0.001$ \\
$\# 2$ & $50 \mu \mathrm{M}$ & $32 \%$ & $63 \%$ & $<0.001$ \\
\hline
\end{tabular}

Cells were analyzed by alkaline comet assay at $3 \mathrm{~h}$ after drug treatment. The percentage of cells with single strand breaks in control groups (untreated or $A B$

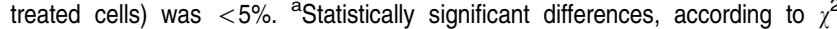
contingency test, between groups treated with Me-Lex and groups treated with Me-Lex $+\mathrm{AB}$ are indicated. Differences between control and Me-Lex treated groups were always highly significant $(P<0.001)$ case the percentage of necrotic cells was always lower than that observed in cells treated with the same concentration of Me-Lex used as a single agent.

The enhancing effect, mediated by PARP inhibitor, on the antiproliferative activity of Me-Lex was accompanied by a pronounced down-regulation of c-myc transcript. Decrease of c-myc expression more likely reflected druginduced growth inhibition rather than apoptosis, since it was observed also in tumor cells treated with only Me-Lex, at concentrations that saturated cell repair ability and mainly induced death by necrosis.

Necrosis generally represents the cell response to a massive injury, including that induced by cytotoxic agents. One of the early changes in cells undergoing necrotic cell death is the loss of membrane integrity, that is evidenced by staining with charged cationic dyes, such as $\mathrm{PI}$, which are normally excluded by live cells and during the initial phases of apoptosis. ${ }^{18} \mathrm{AV}$ and $\mathrm{PI}$ positive cells can also include apoptotic cells undergoing secondary necrosis. ${ }^{23}$ In the case of Me-Lex, the appearance of PI+AV - cells together with $\mathrm{PI}+\mathrm{AV}+$ cells preceded the detection of a high percentage of apoptotic cells $(\mathrm{PI}-\mathrm{AV}+)$, thus making it unlikely that $\mathrm{PI}+\mathrm{AV}+$ cells are derived from the apoptotic compartment. In fact, when a necrotic stimulus (heat shock at $60^{\circ} \mathrm{C}$ ) was applied to tumor cells, an elevated number of $\mathrm{PI}+\mathrm{AV}-$ cells preceded the progressive increase of $\mathrm{PI}+\mathrm{AV}+$ cells.

Appearance of necrotic cells correlated with early down-regulation of telomerase activity. Telomerase is a ribonucleoprotein enzyme which stabilizes telomere length by synthesizing telomere repeats at chromosome ends. ${ }^{24}$ The enzyme is a large multiprotein complex with two core elements represented by the ribonucleoprotein component TR and the catalytic subunit TERT. ${ }^{25,26}$ Its activity is down-regulated in most normal human tissues, whereas it is reactivated in the vast majority of cancer cells, making it an almost ubiquitous tumor marker. ${ }^{27}$ Killing of tumor cells induced by anticancer agents was found to be associated with a decline of telomerase activity. ${ }^{19-21}$ In particular, it has been demonstrated that tumor cells with disrupted plasma membrane and consequent PI staining, after exposure to cytotoxic compounds, showed a reduction of telomerase activity. ${ }^{28}$ In the present study, rapid down-regulation of telomerase activity was observed in tumor cells after treatment with Me-Lex concentrations that induced the early appearance of necrotic cells. Since necrosis is characterized by rapid damage of plasma membrane and release of cytoplasmic constituents, it can be hypothesized that release of proteolytic enzymes might result in prompt abrogation of several enzymatic functions, including telomerase. Suppression of telomerase activity was not due to a direct effect of the methylating agent on the protein itself or on Taq polymerase, since addition of the drug to the reaction mixture, containing cell extracts, did not affect the enzymatic activity. Moreover, it can be excluded that dying cells might release inhibitor factors that down-regulate enzyme activity or affect the TRAP assay, since cell lysates from Me-Lex treated cells did not modify telomerase activity of untreated controls (Figure 8). 
Importantly, $24 \mathrm{~h}$ after treatment, when the same drug concentrations were associated with PARP inhibitor, telomerase activity was comparable to that detectable in control groups, even though growth inhibition was similar to or even more pronounced than that induced by MeLex alone. At this time point, the drug combination mainly induced apoptotic cell death, as indicated by AV staining, hypodiploid DNA content and caspase-3 activation. Persistence of telomerase activity in cells undergoing apoptosis is consistent with previous studies indicating that the enzyme remains active at an early stage of the

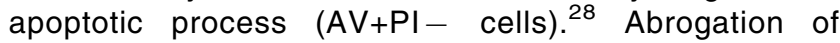
telomerase activity in cells treated with the drug combination, $72 \mathrm{~h}$ after drug exposure, might reflect inactivation of the enzyme as a consequence of necrosis secondary to late phases of apoptosis. The expression of catalytic subunit of telomerase was markedly reduced in MT-1 cells treated with $25 \mu \mathrm{M}$ Me-Lex, alone or combined with $A B$. This effect was paralleled by a marked down-regulation of c-myc, that is regarded as an activator of hTERT expression. ${ }^{29,30}$ The absence of a correlation between telomerase activity and hTERT transcript in cells treated with $25 \mu \mathrm{M}$ Me-Lex+AB at $24 \mathrm{~h}$, might be due to the high stability of the protein complex, which has been shown to possess a long halflife $(>24 \mathrm{~h}){ }^{31,32}$ In addition, the transcript corresponding to the hTR component, that is ubiquitously expressed, regardless of telomerase activity, was not modulated by drug treatment.

In both MT-1 and Jurkat cells exposed to high Me-Lex concentrations combined with $A B$, the number of single strand breaks was higher than that detected in cells treated with the single agent. This is likely the consequence of the interruption of BER-process after the initial MPG removal of N3-MeA adducts, due to PARP inhibition. Since single strand breaks can trigger the apoptotic process, it is likely that increased apoptosis produced by the drug combination might follow enhanced strand break generation. Moreover, it can be hypothesized that reduction of necrosis in response to high Me-Lex concentrations and PARP inhibitor, might be due to the ability of $A B$ to bind the nicotinamide binding domain of PARP, thus preventing NAD+ drop and the consequent depletion of the ATP pool that causes necrosis. Consistently, it has recently been shown that in cells harboring a cleavage-resistant mutant of PARP, apoptotic stimuli induced necrosis and accelerated apoptosis, whereas addition of $A B$ inhibited necrosis and increased apoptosis. ${ }^{5}$

In the case of high levels of unrepaired N3-MeA adducts, apoptosis does not seem to be the prevalent and exclusive cellular response to DNA injury. It can be hypothesized that the inhibitory effect on DNA synthesis, through the block of interaction between polymerase and N3-MeA, might result in necrosis. However, it cannot be excluded that DNA damage provoked by Me-Lex might induce activation of PARP. In this case, synthesis of poly(ADP-ribose) polymers would lead to NAD+ consumption, depletion of the ATP pool and eventually necrosis.

In conclusion, the results of this study indicate that the type of $\mathrm{DNa}$ damage induced by the drug combination differs from that provoked by Me-Lex alone, accounting for distinct modalities of cell death and different kinetics of reduction in telomerase activity.

\section{Materials and Methods}

\section{Cell lines and culture conditions}

The T-lymphoblastic leukemia Jurkat cell line was purchased from the American Type Culture Collection (ATCC, Rockville, MD, USA). The human lymphoblastoid MT-1 cell line ${ }^{33}$ was a generous gift from WG Thilly (Massachusetts Institute of Technology, Cambridge, MA, USA). Both MT-1 and Jurkat are MRS-deficient cell lines. ${ }^{33,34}$ Cell lines were cultured in RPMI-1640 (Gibco, Paisley, Scotland, UK) supplemented with $10 \%$ fetal calf serum (Gibco), $2 \mathrm{mM} \mathrm{L-}$ glutamine, 100 units $/ \mathrm{ml}$ penicillin and $100 \mu \mathrm{g} / \mathrm{ml}$ streptomycin (Flow Laboratories, McLean, VA, USA) at $37^{\circ} \mathrm{C}$ in a $5 \% \mathrm{CO}_{2}$ humidified atmosphere.

\section{Drugs}

Me-Lex was prepared as previously described. ${ }^{35}$ The PARP inhibitor $A B$ was purchased from Sigma (St. Louis, MO, USA). Drug stock solutions were prepared by dissolving Me-Lex in $95 \%$ ethanol $(10 \mathrm{mM})$, and $A B$ in RPMI-1640 (16 mM). The final concentration of ethanol in drug treated cultures was always less than $0.5 \%(\mathrm{v} / \mathrm{v})$ and did not contribute to toxicity (data not shown).

\section{Drug treatment and cell growth evaluation}

Cells were cultured in flasks (Falcon, Becton \& Dickinson Labware, Oxnard, CA, USA) at the concentration of $3 \times 10^{5} \mathrm{cells} / \mathrm{ml}$. Inhibition of PARP was obtained by treating cells with $4 \mathrm{mM} \mathrm{AB}$ concentration which has been described as completely inhibiting PARP activity. ${ }^{36}$ Me-Lex was added to cell cultures, either alone or immediately after $A B$ addition, and it was used at concentrations ranging from 1.5 to $50 \mu \mathrm{M}$. Cells were then incubated at $37^{\circ} \mathrm{C}$ for 3 days and growth was evaluated, every $24 \mathrm{~h}$, by counting cells in quadruplicate. Cell viability was determined by Trypan blue dye exclusion.

\section{Annexin V assay}

The AV assay permits the simultaneous quantification of viable, apoptotic and necrotic cells. ${ }^{18}$ Phosphatidylserine exposure was assessed with an AV-fluorescein isothiocianate (FITC) conjugate using an apoptosis detection kit (Bender Medsystem Diagnostic, Vienna, Austria), according to manufacturer's instructions. Briefly, at different times after drug exposure, cells were harvested and washed in PBS. Then, cells $\left(1 \times 10^{6}\right)$ were labeled with AV-FTIC $(0.25 \mu \mathrm{g} / \mathrm{ml})$ in $100 \mu$ l binding buffer containing $10 \mathrm{mM} \mathrm{Hepes} / \mathrm{NaOH}, 140 \mathrm{mM} \mathrm{NaCl}$ and $2.5 \mathrm{mM} \mathrm{CaCl}_{2}, \mathrm{pH}$ 7.4. After $10 \mathrm{~min}$, cells were washed and suspended in binding buffer containing $2 \mu \mathrm{g} / \mathrm{ml} \mathrm{PI}$. After labeling, cells were immediately analyzed using the FACSscan flow cytometer (Becton and Dickinson, San Jose, CA, USA). Cell debris was excluded by appropriate forward and side scatter gating. Five thousand cells were analyzed in each condition. Four quadrants of cytograms were set using negative controls. The proportions of vital cells (AV $-\mathrm{PI}-$ ), apoptotic cells $(\mathrm{AV}+\mathrm{PI}-)$, and necrotic cells ( $\mathrm{AV}-\mathrm{PI}+; \mathrm{AV}+\mathrm{PI}+)$ present in each quadrant were expressed as percentage of the total cell population. 


\section{Caspase-3 activity assay}

Caspase-3 activity was determined using a specific Kit (Pharmingen, San Diego, CA, USA) according to the manufacturer's instructions. This assay is based on spectrofluorimetric detection of the fluorescent 7-amino-4-methylcoumarin (AMC) that is released after cleavage of a synthetic tetrapeptide fluorogenic substrate (Ac-DEVD-AMC) by the active form of caspase-3. In selected groups, the inhibitor Ac-DEVD$\mathrm{CHO}$ was used to specifically block caspase-3 activity in cell lysates. The release of fluorescent AMC was quantified in cell lysates by ultraviolet spectrofluorometry using an excitation of $380 \mathrm{~nm}$ and an emission wavelength range of $420-460 \mathrm{~nm}$.

\section{Evaluation of telomerase activity}

The TRAP assay, based on PCR amplification of telomerase extension products, was performed as previously described ${ }^{37}$ with minor modifications. ${ }^{38}$ Extracts were prepared by lysing the cells in icecold extraction buffer [0.5\% NP40, $10 \mathrm{mM}$ Tris- $\mathrm{HCl}(\mathrm{pH} 7.5), 1 \mathrm{mM}$ $\mathrm{MgCl}_{2}, 1 \mathrm{mM}$ EGTA, $0.25 \mathrm{mM}$ sodium deoxycholate, $150 \mathrm{mM} \mathrm{NaCl}$, $10 \%$ glycerol, $5 \mathrm{mM} \beta$-mercaptoethanol, $0.1 \mathrm{mM} 4$-(2-aminoethyl)benzene-sulfonyl fluoride hydrochloride]. Four $\mu \mathrm{l}$ of cell extracts, corresponding to $2 \times 10^{2}$ MT- 1 or Jurkat cells were used for TRAP assay. The telomerase reaction was carried out in $40 \mu \mathrm{l}$ of the reaction mixture consisting of $20 \mathrm{mM}$ Tris- $\mathrm{HCl}(\mathrm{pH} 8.3), 68 \mathrm{mM} \mathrm{KCl}, 1.5 \mathrm{mM}$ $\mathrm{MgCl}_{2}, 1 \mathrm{mM}$ EGTA, $0.05 \%$ Tween $20,0.1 \mu \mathrm{g}$ of TS primer (5'AATCCGTCGAGCAGAGTT-3'), $0.1 \mu \mathrm{M}$ T4 gene 32 protein and $50 \mu \mathrm{M}$ of each deoxynucleotide triphosphate. Samples were incubated at room temperature for $15 \mathrm{~min}$ to allow telomerase to extend TS primer. The reaction was stopped in ice and 2 units of Taq DNA polymerase, $0.16 \mu \mathrm{l}$ of $\alpha\left[{ }^{32} \mathrm{P}\right] \mathrm{dCTP}(3000 \mathrm{Ci} / \mathrm{mmol}$, NEN Life Science Products, Boston, MA, USA) and $0.1 \mu \mathrm{g}$ of $\mathrm{CX}$ oligonucleotide (5'CCCTTACCCTTACCCTTACCCTAA-3') were added to each single PCR tube. Amplification of the telomeric products was performed by PCR $\left(94^{\circ} \mathrm{C}, 30 \mathrm{~s} ; 50^{\circ} \mathrm{C}, 30 \mathrm{~s} ; 72^{\circ} \mathrm{C}, 1 \mathrm{~min} ; 31\right.$ cycles $)$. After the TRAP assay, $40 \mu \mathrm{l}$ of the PCR reaction were separated on a $10 \%$ nondenaturing polyacrylamide gel. Subsequently, gels were fixed and exposed to X-ray films (Kodak, Rochester, NY, USA) at $-80^{\circ} \mathrm{C}$. The signal of the telomeric ladder was quantified by bidimensional densitometry using a BioRad (Richmond, CA, USA) scanning apparatus (Imaging densitometer, GS-670; Molecular Analyst software) and each value was corrected for the background (i.e., lanes relative to lysis buffer).

The in vitro direct effect of the methylating agent on telomerase activity was analyzed by adding the drug or the appropriate dilution of drug vehicle directly to the telomerase reaction mixture, before TS primer addition. Samples were incubated $1 \mathrm{~h}$ at $37^{\circ} \mathrm{C}$ and then processed for the TRAP assay. Moreover, the influence of Me-Lex on the activity of Taq polymerase was assessed by directly adding the compound to the PCR reaction mixture.

Assay of alkaline phosphatase activity as an internal control for the quality of the cell extract was performed using a commercially available kit (Sigma) as previously described. ${ }^{37}$

\section{Northern blot analysis}

Total cellular RNA was extracted using the TriPure isolation reagent (Roche, Milan, Italy). RNAs (15 $\mu \mathrm{g}$ ) were fractionated by electrophoresis on a formaldehyde-containing $1.2 \%$ agarose gel. The integrity of RNA was confirmed by RNA visualization, by adding ethidium bromide to the RNA gel loading buffer. RNA was transferred to a nylon membrane (Gene Screen Plus ${ }^{\circledR}$, NEN Life Science Products, Boston, MA, USA) and hybridized at $68^{\circ} \mathrm{C}$ for $1 \mathrm{~h}$ with $\alpha\left[{ }^{32} \mathrm{P}\right] \mathrm{dCTP}$-labeled probe (3000 Ci/mmol, NEN Life Science Products) using the QuickHyb hybridization solution (Stratagene, Cambridge, UK). Washing of the blots was performed according to the manufacturer's instructions. The blotted membrane was exposed to X-ray film at $-80^{\circ} \mathrm{C}$. Bidimensional densitometry of the blots was performed using an Imaging densitometer, GS-670 (BioRad).

The c-myc probe was purchased from ATCC; the probe corresponding to the RNA component of human telomerase (hTR), a $0.56 \mathrm{~Kb}$ fragment cloned into the Sacl site of pGEM-5Z plasmid (Promega Corp., Madison, WI, USA), was obtained from Geron Corp. (Menlo Park, CA, USA) and the GAPDH probe, a $0.9 \mathrm{~Kb}$ EcoRI fragment of the human GAPDH gene, was a generous gift from Dr. R Dalla Favera (Department of Pathology, Columbia University, New York, NY, USA).

\section{Reverse-transcription/polymerase-chain reaction (RT-PCR)}

Analysis of the expression of the human telomerase catalytic subunit hTERT was performed by RT-PCR as previously described, with minor modifications. ${ }^{39}$ Messenger RNA was isolated from tumor cells using the Micro-FastTrack ${ }^{T M}$ kit (Invitrogen, Carlsbad, CA, USA) in accordance with the manufacturer's protocol. Fifty ng for each mRNA sample were used for cDNA synthesis using the cDNA cycle ${ }^{\circledR}$ Kit (Invitrogen) with random primers. To amplify cDNA, $5 \mu$ laliquots of the reverse-transcribed cDNA were subjected to 28 cycles of PCR in $50 \mu \mathrm{l}$ of $1 \times$ buffer $(10 \mathrm{mM}$ Tris- $\mathrm{HCl}, \mathrm{pH} 8.3,1.5 \mathrm{mM} \mathrm{MgCl} 2,50 \mathrm{mM} \mathrm{KCl}$ ) containing $1 \mathrm{mM}$ each of dATP, dCTP, dGTP and dTTP, $2.5 \mu \mathrm{Ci}$ of $\alpha\left[{ }^{32} \mathrm{P}\right] \mathrm{dCTP}, 2.5 \mathrm{U}$ of Taq DNA polymerase (Roche) and $0.2 \mathrm{mM}$ of specific primers. Each cycle consisted of denaturation at $94^{\circ} \mathrm{C}$ for $30 \mathrm{~s}$, annealing at $60^{\circ} \mathrm{C}$ for $30 \mathrm{~s}$ and extension at $72^{\circ} \mathrm{C}$ for $45 \mathrm{~s}$. PCR products were electrophoresed using a $7 \%$ polyacrylamide gel and visualized by autoradiography. The primer pairs used for hTERT amplification were 5'-CGGAAGAGTGTCTGGAGCAA-3' (LT5) and 5'GGATGAAGCGGAGTCTGGA-3' (LT6), and amplified a $145 \mathrm{bp}$ product. $^{39}$

The primers used for GAPDH amplification (5'-TGGTATCGTGGAAGGACTCATGAC-3' and 5'-ATGCCAGTGAGCTTCCCGTTCAGC-3') amplified a 190 bp product.

\section{Single strand break detection by alkaline comet assay}

The assay was performed as previously described with modifications. ${ }^{40}$ Three hours after drug treatment, cells were harvested and centrifuged at $200 \times g$ for $5 \mathrm{~min}$ and diluted in RPMl-1640. Cell suspension $\left(0.5 \mathrm{ml}\right.$ of $3 \times 10^{5}$ cells $\left./ \mathrm{ml}\right)$ was gently mixed with $0.5 \mathrm{ml}$ of pre-warmed low melting point agarose type VII (1.5\% in PBS). This preparation was then spread onto microscope slides pre-coated with $1 \%$ agarose type $1-\mathrm{A}$ in distilled water. Slides were then covered with a coverslip to give an uniform gel. Triplicate slides were prepared for each treatment. Thereafter, coverslips were removed and slides were submerged in ice-cold lysis buffer $(2.5 \mathrm{M} \mathrm{NaCl}, 100 \mathrm{mM}$ EDTA and $10 \mathrm{mM}$ Tris- $\mathrm{HCl} \mathrm{pH} 11.5$, containing $1 \%$ Triton $\mathrm{X}-100$, added just before use). After washing, using four changes of distilled water, slides were arranged length-wise in an electrophoresis tank and submerged in alkaline buffer ( $50 \mathrm{mM} \mathrm{NaOH}$ and $1 \mathrm{mM}$ EDTA pH 12.5) for $45 \mathrm{~min}$. Electrophoresis was run at $25 \mathrm{~V}, 300 \mathrm{~mA}$, for $10 \mathrm{~min}$. Slides were removed and washed with neutralization buffer $0.5 \mathrm{M}$ Tris- $\mathrm{HCl} \mathrm{pH} 7.5$ for $10 \mathrm{~min}$, followed by a PBS wash. Thereafter, slides were air dried overnight at room temperature, re-hydrated with distilled water and then stained with $2.5 \mu \mathrm{g} / \mathrm{ml}$ PI for 20-30 min and de-stained for additional $30 \mathrm{~min}$ in water. 
Slides, kept in a humidified chamber, were observed under a fluorescence microscope the same day of electrophoresis, or the following day after a night at $4^{\circ} \mathrm{C}$. Two to three hundred cells were generally observed for each slide, blindly. A contingency $\chi^{2}$ test was performed to evaluate the differences in the number of comets and of normal round nuclei between control and treated samples or between groups treated with Me-Lex only and those treated with Me-Lex $\pm A B$.

\section{Acknowledgements}

This study was supported by a grant from the Italian Association for Cancer Research (AIRC) and, partly, by MURST funds to E Bonmassar (Molecular bases for the pharmacological control of neoplastic diseases). The authors wish to thank Dr. Pedro Miguel Lacal (IDI, IRCCS, Rome, Italy), Dr. Antonio Mastino (University of Messina, Italy) and Dr. Fulvio Erba (University of Rome 'Tor Vergata', Italy) for suggestions and discussion.

\section{References}

1. DantzerF, Schreiber V, Niedergang C, Trucco C, Flatter E, De La Rubia G, Oliver J, Rolli V, Menissier-de Murcia J and de Murcia G (1999) Involvement of poly(ADP-ribose) polymerase in base excision repair. Biochimie 81: 69-75

2. D'Amours D, Desnoyers S, D'Silva I and Poirier GG (1999) Poly(ADPribosyl)ation reactions in the regulation of nuclear functions. Biochem. J. 342: $249-268$

3. Kaufmann SH, Desnoyers S, Ottaviano Y, Davidson NE and Poirier GG (1993) Specific proteolytic cleavage of poly(ADP-ribose) polymerase: an early marker of chemotherapy-induced apoptosis. Cancer Res. 53: 3976-3985

4. Lazebnik YA, Kaufmann SH, Desnoyers S, Poirier GG and Earnshaw WC (1994) Cleavage of poly(ADP-ribose) polymerase by a proteinase with properties like ICE. Nature 371: 346-347

5. Herceg Z and Wang Z-Q (1999) Failure of poly(ADP-ribose) polymerase cleavage by caspases leads to induction of necrosis and enhanced apoptosis. Mol. Cell Biol. 19: 5124-5133

6. Lindahl T, Karran P and Wood RD (1997) DNA excision repair pathways. Curr. Opin. Genet. Dev. 7: 158-169

7. Wilson III DM and Thompson LH (1997) Life without DNA repair. Proc. Natl. Acad. Sci. USA 94: $12754-12757$

8. Engelward BP, Allan JM, Dreslin AJ, Kelly JD, Wu MM, Gold B and Samson LD (1998) A chemical and genetic approach together define the biological consequences of 3-methyladenine lesions in the mammalian genome. J. Biol. Chem. 273: 5412-5418

9. Tentori L, Vernole P, Lacal PM, Madaio R, Portarena I, Levati L, Balduzzi A, Turriziani M, Dande P, Gold B, Bonmassar E and Graziani G (2000) Cytotoxic and clastogenic effects of a DNA minor groove binding methyl sulfonate ester in mismatch repair deficient leukemic cells. Leukemia 14: 1451-1459

10. Encell L, ShukerDE, Foiles PG and GoldB (1996) The in vitro methylation of DNA by a minor groove binding methyl sulfonate ester. Chem. Res. Toxicol. 9: 563567

11. Kelly JD, Inga A, Chen FX, Dande $P$, Shah D, Monti $P, A$, prile A, Burns PA, Scott G, Abbondandolo A, Gold B and Fronza G (1999) Relationship between DNA methylation and mutational patterns induced by a sequence selective minor groove methylating agent. J. Biol. Chem. 274: 18327-18334

12. Newlands ES, Stevens MFG, Wedge SR, Wheelhouse RT and Brock C (1997) Temozolomide: a review of its discovery, chemical properties, pre-clinical development and clinical trials. Cancer Treat. Rev. 23: 35-61

13. D'Atri S, Tentori L, Lacal PM, Graziani G, Pagani E, Benincasa E, Zambruno G, Bonmassar E and Jiricny J (1998) Involvement of the mismatch repair system in temozolomide-induced apoptosis. Mol. Pharmacol. 54: 334-341

14. Jiricny J (1998) Eukaryotic mismatch repair: an update. Mutat. Res. 409: 107121

15. Jiricny J and Nyström-Lahti M (2000) Mismatch repair defects in cancer. Curr. Opin. Genet. Dev. 10: 157-161
16. Fink D, Aebi S and Howell SB (1998) The role of DNA mismatch repair in drug resistance. Clin. Cancer Res. 4:1-6

17. Nicholson DW, Ali A, Thornberry NA, Vaillancourt JP, Ding CK, Gallant $M$, Gareau Y, Griffin PR, Labelle M and Lazebnik YA (1995) Identification and inhibition of the ICE/CED-3 protease necessary for mammalian apoptosis. Nature 376: $37-43$

18. Vermes I, Haanen C, Steffens-Nakken H and Reutelingsperger C (1995) A novel assay for apoptosis. Flow cytometry detection of phosphatidylserine expression on early apoptotic cells using fluorescein labeled Annexin V. J. Immunol. Methods 184: $39-51$

19. Faraoni I, Turriziani M, Masci G, De Vecchis L, Shay JW, Bonmassar E and Graziani G (1997) Decline in telomerase activity as a measure of tumor cell killing by antineoplastic agents in vitro. Clin. Cancer Res. 3: 579-585

20. Faraoni I, Graziani G, Turriziani M, Masci G, Mezzetti M, Testori A, Veronesi U and Bonmassar E (1999) Suppression of telomerase activity as an indicator of drug-induced cytotoxicity against cancer cells: in vitro studies with fresh human tumor samples. Lab. Invest. 79: 993-1005

21. Faraoni I, Bonmassar E and Graziani G (2000) Telomerase as a potential anticancer target: growth inhibition and genomic instability. Drug Resistance Updates 3: 3-6

22. Fortini P, Raspaglio G, Falchi Mand Dogliotti E (1996) Analysis of DNA alkylation damage and repair in mammalian cells by the comet assay. Mutagenesis 11: $169-175$

23. Darzynkiewicz Z, Juan G, Li X, Gorczyca W, Murakami T and Traganos F (1997) Cytometry in cell necrobiology: analysis of apoptosis and accidental cell death (necrosis). Cytometry 27: 1-20

24. Morin GB (1989) The human telomere terminal transferase enzyme is a ribonucleoprotein that synthesizes TTAGGG repeats. Cell 59: 521-529

25. Feng J, Funk WD, Wang SS, Weinrich SL, Avilion AA, Chiu CP, Adams RR, Chang E, Allsopp RC, YuJ, Le S, West MD, Harley CB, Andrews WH, GreiderCW and Villeponteau B (1995) The RNA component of human telomerase. Science 269: $1236-1241$

26. Nakamura TM, Morin GB, Chapman KB, Weinrich SL, Andrews WH, Lingner J, Harley CB and Cech TR (1997) Telomerase catalytic subunit homologs from fission yeast and human. Science 277: 955-959

27. ShayJWand Bacchetti S (1997) A survey of telomerase activity in human cancer. Eur. J. Cancer 33: 787-791

28. Akiyiama M, Horiguchi-Yamada J, Saito S, Hoshi Y, Yamada O, Mizoguchi Hand Yamada H (1999) Cytostatic concentrations of anticancer agents do not affect telomerase activity of leukaemic cells in vitro. Eur. J. Cancer 35: 309-315

29. Wu KJ, Grandori C, Amacker M, Simon-Vermot N, Polack A, Lingner J and DallaFavera R (1999) Direct activation of TERT transcription by c-MYC. Nat. Genet. 21: $220-224$

30. Greenberg RA, O'Hagan RC, Deng H, Xiao Q, Hann SR, Adams RR, Lichtsteiner S, Chin L, Morin GB and DePinho RA (1999) Telomerase reverse transcriptase gene is a direct target of C-Myc but is not functionally equivalent in cellular transformation. Oncogene 18: 1219-1226

31. Holt SE, Wright WE and Shay JW (1996) Regulation of telomerase activity in immortal cell lines. Mol. Cell Biol. 16: 2932-2939

32. Holt SE, Aisner DL, Shay JW and Wright WE (1997) Lack of cell cycle regulation of telomerase activity in human cells. Proc. Natl. Acad. Sci. USA 94: 1068710692

33. Kat A, Thilly WG, Fang WH, Longley MJ, Li GM and Modrich P (1993) An alkylation-tolerant, mutator human cell line is deficient in strand-specific mismatch repair. Proc. Natl. Acad. Sci. USA 90: 6424-6428

34. Levati L, Marra G, Lettieri T, D'Atri S, Vernole P, Tentori L, Lacal PM, Pagani E, Bonmassar E, Jiricny J and Graziani G (1998) Mutation of the mismatch repair gene hMSH2 and hMSH6 in a human T-cell leukemic line tolerant to methylating agents. Gene Chromosome Cancer 3: 159-166

35. Zhang Y, Chen F-X, Metha P and Gold B (1993) The design of groove and sequence selective alkylation of DNA by sulfonate esters tethered to lexitropsins. Biochemistry 32: 7954-7965

36. Boulton S, Pemberton LC, Porteous JK, Curtin NJ, Griffin RJ, Golding BT and Durkacz BW (1995) Potentiation of temozolomide induced cytotoxicity: a comparative study of the biological effects of poly(ADP-ribose) polymerase inhibitors. Brit. J. Cancer 72: 849-856 
37. Piatyszek MA, Kim NW, Weinrich SL, Hiyama K, Hiyama E, Wright WE and Shay JW (1995) Detection of telomerase activity in human cells and tumors by a telomeric repeat amplification protocol (TRAP). Methods Cell Sci. 17: 1-15

38. Norton JC, Holt SE, Wright WE and Shay JW (1998) Enhanced detection of human telomerase activity. DNA Cell. Biol. 17: 217-219
39. Kanaya T, Kyo S, Takakura M, Ito H, Namiki M and Inoue M (1998) hTERT is a critical determinant of telomerase activity in renal-cell carcinoma. Int. J. Cancer 78: $539-543$

40. Olive PL and Banath J (1997) Multicell spheroid response to drugs predicted with the comet assay. Cancer Res. 57: 5528-5533 